\title{
SELF EFFICACY DAN KECEMASAN DALAM MENGHADAPI TUGAS AKHIR PADA MAHASISWA UKWMS
}

\author{
Sarah Florencea \\ Elisabet Widyaning Hapsari \\ Fakultas psikologi universitas Katolik Widya Mandala Surabaya
}

\begin{abstract}
ABSTRAKSI
Penelitian ini bertujuan untuk mengetahui hubungan kecemasan pada mahasiswa yang mengambil tugas akhir sebagai persyaratan kelulusan mahasiswa strata 1 di UKWMS ditinjau dari self efficacy. Berdasarkan salah satu faktor yang dapat mempengaruhi kecemasan yaitu self efficacy yang rendah. Keterkaitan antara kecemasan menghadapi tugas akhir dengan self efficacy adalah jika mahasiswa percaya bahwa tidak punya kemampuan untuk menanggulangi tantangan-tantangan yang penuh stress dalam menghadapi tugas akhir, maka mahasiswa tersebut akan merasa semakin cemas bila berhadapan dengan tantangan-tantangan tersebut. Ketika mahasiswa mempunyai self efficacy yang tinggi maka mahasiswa tersebut dapat mengatasi kecemasan yang dihadapinya dan keadaan yang menantang ataupun yang sulit tersebut dapat diibaratkan suatu tantangan yang tidak perlu dihindari. Subjek dalam penelitian ini adalah 341 mahasiswa UKWMS yang sedang menghadapi tugas akhir. Teknik sampling yang digunakan adalah proportional stratified random sampling. Hasil pengolahan statistik memperoleh koefisien kolerasi sebesar $-0,376$ dengan nilai $p$ sebesar $0,000(p<0,05)$ yang berarti terdapat hubungan yang negatif antara self efficacy dengan kecemasan dalam menghadapi tugas akhir. Semakin mahasiswa tidak mempunyai kemampuan dalam mengatasi tugas akhir maka mahasiswa tersebut akan semakin merasa cemas dan jika mahasiswa tersebut memiliki kepercayaan diri terkait tugas akhir maka mahasiswa tersebut dapat mengatasi rasa cemasnya dan mahasiswa tersebut tidak menghindari stressor yang mahasiswa tersebut cemaskan. Berdasarkan hasil penelitian ini, self efficacy terbukti memberikan sumbangan efektif sebesar $14 \%$, sementara kemungkinan sebesar $86 \%$ bisa dipengaruhi oleh variabel lain yang tidak diteliti seperti dukungan sosial (Yunita, 2013), religiusitas (Hidayatin \& Darmawati, 2013) dan sebagainya.
\end{abstract}

Kata kunci: kecemasan, tugas akhir, self efficacy, mahasiswa UKWMS

\section{ABSTRACT}

This study aims to determine the relationship of anxiety to students who take the final assignment as a requirement for graduating undergraduate students at UKWMS in terms of self efficacy. Based on one of the factors that can affect anxiety, namely low self efficacy. The link between anxiety facing the final task with self efficacy is that if students believe that they do not have the ability to overcome stressful challenges in the face of the final task, the student will feel increasingly anxious when faced with these challenges. When students have high selfefficacy, the student can overcome the anxiety he faces and challenging or difficult conditions can be likened to a challenge that need not be avoided. The subjects in this study were 341 UKWMS students who were facing the final assignment. The sampling technique used is proportional stratified random sampling. The results of statistical processing obtained a correlation coefficient of -0.376 with a $p$ value of $0.000(p<0.05)$ which means that there is a negative relationship between self efficacy and anxiety in facing the final task. The more students do not have the ability to overcome the final assignment, the student will feel increasingly anxious and if the student has confidence in the final assignment, the student can overcome his anxiety and the student does not avoid the stressors that the student is worried about. Based on the results of this study, self efficacy is proven to provide an effective 
contribution of $14 \%$, while the probability of $86 \%$ can be influenced by other variables not examined such as social support (Yunita, 2013), religiosity (Hidayatin \& Darmawati, 2013) and so on.Keyword: anxiety in facing final task, self efficacy, students taking on the final task.

Keywords: anxiety, final assignment, self efficacy, UKWMS students

\section{PENDAHULUAN}

Perguruan tinggi merupakan institusi pendidikan yang menuntut setiap lulusan menjadi individu yang memiliki tingkat intelektual yang tinggi, kecerdasan dalam perencanaan dan bertindak, serta dapat berpikir kritis. Tuntutan-tuntutan tersebut diwadahi oleh perguruan tinggi berupa pemenuhan tugas akhir. Tugas akhir merupakan salah satu persyaratan kelulusan mahasiswa yang berbentuk penulisan karya ilmiah yang disusun oleh mahasiswa setiap program studi, tugas akhir ini dapat berupa jalur skripsi dan jalur nonskripsi. Berdasarkan Peraturan Akademik 2014 (UKWMS, 2014: 9) dalam menyusun skripsi, mahasiswa dibimbing oleh maksimum dua pembimbing.

Peneliti mengadakan preliminary dengan menyebarkan kuesioner tentang kecemasan menghadapi tugas akhir pada tanggal 1 Maret 2017 pada mahasiswa Fakultas Psikologi UKWMS yang menghadapi tugas akhir. Dari 29 orang yang mengisi kuesioner yang disebarkan oleh peneliti, terdapat 25 orang yang mengalami kecemasan dalam menghadapi tugas akhir. Berikut data tentang hal yang membuat mahasiswa mengalami kecemasan:

Tabel 1.1. Hal-hal yang membuat mahasiswa mengalami kecemasan

\begin{tabular}{ll}
\hline Hal yang membuat cemas & Total \\
\hline Pengambilan data & 16 \\
Pengolahan data & 13 \\
Pembahasan hasil & 3 \\
Penarikan kesimpulan & 4 \\
Pembuatan laporan & 15 \\
Sidang / presentasi & 17 \\
Dosen pembimbing & 8 \\
Pengerjaan melebihi deadline & 18 \\
\hline
\end{tabular}

Berdasarkan tabel 1.1 yang membuat individu mengalami kecemasan adalah pengerjaan yang melebihi deadline, saat sidang atau presentasi, pembuatan laporan dan pada saat pengambilan data. Santrock (2011: 546) menyatakan bahwa mahasiswa mengalami kecemasan karena selama semester-semester sebulumnya, mahasiswa tersebut mendapatkan evaluasi dari tugas-tugas kuliah, pernah mengalami kegagalan pada tugas-tugas tertentu sehingga memunculkan suatu labeling pada diri mahasiswa tersebut terkait kemampuan dalam menghadapi tugas akhir. 
Kecemasan tersebut terlihat juga dari pembicaraan mahasiswa-mahasiswa di Fakultas Psikologi Universitas Katolik Widya Mandala Surabaya (UKWMS) saat mengisi Kartu Rancangan Studi (KRS) manual pada tanggal 11 Januari 2017;

"looh kamu ambil propskrip ta.. aduh aku galau pek ambil apa endak, nanti takot ga isa ngerjain”. (subjek D, 20 tahun)

Pernyataan-pernyataan seperti itu juga diungkapkan oleh mahasiswa lain. "Kegalauan” yang dirasakan masih belum jelas. Hal tersebut sejalan dengan pendapat Santrock (2011: 529) bahwa "kecemasan merupakan suatu perasaan takut atau kegundaan yang tidak jelas dan tidak menyenangkan".

Kecemasan tidak hanya dialami oleh mahasiswa yang menghadapi tugas akhir berupa skripsi saja, akan tetapi mahasiswa yang menghadapi tugas akhir berupa nonskripsi juga mengalami kecemasan. Berikut hasil wawancara yang dilakukan oleh peneliti pada tanggal 24 April 2017 pada mahasiswa Fakultas Ilmu Komunikasi yang mengambil tugas akhir berupa magang dan dilanjukan dalam penulisan skripsi.

"aku ini magang di perusahaan $x$, yakapa ya ak itu kapanane takot kalo pas ambil data itu dipersulit soale kan ada data sing bersifat rahasia" (subjek F, 22 tahun)

Berdasarkan hasil wawancara tersebut, terlihat adanya mahasiswa yang mengalami kecemasan, secara fisik yang tampak pada subjek B adanya kerigat dingin, anggota tubuh bergetar dan gugup saat mencari jurnal. Secara perilaku pada subjek A tampak seperti perilaku menghindar seperti melihat drama korea dan makan, dan pada subjek A, C, E dan F secara kognitif tampak seperti khawatir tentang sesuatu, keyakinan bahwa sesuatu yang mengerikan akan terjadi seperti tidak mendapatkan subjek penelitian, teori, tentang sidang yang mendatang, tentang hasil penelitian dan menemukan kesulitan-kesulitan. Hal di atas sejalan dengan pendapat Nevid (2002:163) bahwa kecemasan itu sendiri merupakan suatu keadaan aprehensi atau keadaan khawatir yang mengeluhkan bahwa suatu yang buruk akan terjadi.

Berdasarkan hasil preliminary dari kuesioner yang peneliti lakukan tanggal 1 Maret 2017, adanya tiga ciri kecemasan menurut Nevid, dkk (2000: 164) dan frekuensi mahasiswa yang mengalami ciri-ciri tersebut. Ciri fisik bisa berupa kegelisahan/kegugupan sebanyak 23 mahasiswa, pusing sebanyak 16 mahasiswa, merasa sensitif atau mudah marah sebanyak 11 mahasiswa, terdapat gangguan sakit perut atau mual sebanyak 8 mahasiswa dan merasa lemas sebanyak 7 mahasiswa. Ciri perilaku atau behavioural berupa perilaku menghindar sebanyak 15 mahasiswa dan perilaku terguncang sebanyak 13 mahasiswa. Ciri kognitif berupa khawatir 
tentang sesuatu sebanyak 23 mahasiswa, ketakutan akan ketidakmampuan mengatasi masalah sebanyak 15 mahasiswa, tanpa disadari berfikir bahwa semuanya membingungkan sebanyak 14 mahasiswa, pikiran terasa bercampur aduk atau kebingungan sebanyak 13 mahasiswa dan sulit berkonsentrasi atau memfokuskan pikiran sebanyak 13 mahasiswa.

Didukung oleh penelitian dari Anggen (2012) tentang pengaruh relaksasi visualisasi imagery untuk menurunkan kecemasan dalam menghadapi ujian skripsi pada mahasiswa Fakultas Psikologi, adanya kesimpulan bahwa mahasiswa Fakultas Psikologi UKWMS akan semakin tinggi tingkat kecemasannya jika semakin mendekati stressor yang mahasiswa tersebut cemaskan. Dalam hal ini, stressor yang disebut adalah ujian skripsi. Dari hasil kesimpulan tersebut dapat dikatakan bahwa ujian skripsi menimbulkan rasa cemas. Menurut Nevid, dkk (2002:180), salah satu faktor yang mempengaruhi kecemasan yaitu self efficacy yang rendah. Jika mahasiswa percaya bahwa tidak punya kemampuan untuk menanggulangi tantangan-tantangan yang penuh stress dalam menghadapi tugas akhir, maka mahasiswa tersebut akan merasa semakin cemas bila berhadapan dengan tantangan-tantangan tersebut. Didukung dengan penelitian yang dilakukan oleh Wardhani (2015) tentang hubungan antara self efficacy dengan kecemasan menghadapi ujian skripsi pada mahasiswa psikologi Universitas Muhammadyah Surakarta, mendapatkan hasil bahwa ada hubungan negatif yang signifikan antara self efficacy dengan kecemasan menghadapi ujian skripsi.

Self efficacy itu sendiri menurut Bandura yaitu "keyakinan bahwa seseorang dapat menguasai sesuatu dan memproduksi hasil positif". Self efficacy adalah "keyakinan bahwa “aku bisa"”' (Santrock. 2011: 523). Self efficacy merupakan suatu penilaian yang spesifik terkait suatu kejadian dalam keyakinannya pada satu tugas tertentu. Suatu tugas tertentu dalam self efficacy diibaratkan adanya tiga langkah yang mudah yang menghasilkan hasil yang berbeda pada waktu yang berbeda dalam konteks yang berbeda (Maltby, dkk. 1995: 336). Bandura sendiri (dalam Snowman, dkk. 2009: 280) mengidentifikasikan empat tipe perilaku yang dapat berdampak pada level self efficacy individu yaitu selection processes, individu yang mempunyai self efficacy yang tinggi akan mempunyai suatu pertimbangan dalam berbagai macam tujuan dan kegiatan yang akan dia lakukan. Self efficacy pada level selection processes tampak seperti regulasi diri. Dalam fenomena yang terjadi, mahasiswa UKWMS mempunyai pertimbangan dalam melakukan tujuan yang dilakukan dalam menghadapi tugas akhir. Penelitan yang dilakukan oleh Sanitiara, dkk (2014) mengenai hubungan kecemasan akademis dengan regulasi diri dalam belajar pada mahasiswa tahun pertama Fakultas Kedokteran Universitas Riau tahun 2013/2014 dapat disimpulkan bahwa "tidak terdapat hubungan kecemasan akademis dengan regulasi diri dalam belajar $(\mathrm{p}=0,739 ; \mathrm{r}=-0.034)$. Namun terdapat 
salah satu karakteristik kecemasan akademis yang berhubungan dengan regulasi diri dalam belajar yakni perhatian yang menunjukkan arah yang salah/miss attention $(\mathrm{p}=0.016 ; \mathrm{r}=0.239)$ )". Dalam hal tersebut mahasiswa UKWMS melewati tahap selection processes. Hal ini tidak sejalan dengan penelitian yang dilakukan oleh Sanitiara, dkk, yang menunjukkan hasil penelitian adanya korelasi yang negatif antara kecemasan dan regulasi diri. Serta self efficacy tidak hanya dilihat dari selection processes saja tetapi juga dilihat dalam level perilaku cognitive processes, motivational processes, affective prosesses juga. Mahasiswa dalam menghadapi tugas akhir memiliki self efficacy yang rendah. Hal tersebut tampak pada tahap cognitive processes, mahasiswa dengan self efficacy yang rendah akan lebih membayangkan tentang kegagalan. Berikut bukti dari hasil wawancara:

"semuanya serba gak yakin, tapi ya kalo dikira-kira ya setengah-setengah lah" (subjek A, 20 tahun)

"aku sih merasa bisa menghadapi impianku, pengen cepet lulus, ya soalnya aku juga udah punya target tapi ya gak tau lagi kalo gak penuhi target haha” (subjek B, 21 tahun)

"kalo hasil praktikumku ada efektifitasnya ya gak tau sih, tapi kalo gagal ya bisa diulang lagi tapi kalo mentok gak ada efektifitasnya yauda, ya memang penelitianku ini gak ada

Menurut Santrock (2011: 523) seorang mahasiswa yang mempunyai self efficacy yang rendah kemungkinan akan menghindari tugas-tugas yang khususnya pada tugas yang menurutnya menantang ataupun sulit bagi mahasiswa tersebut, pada hal ini dalam menghadapi tugas akhir, sedangkan mahasiswa yang mempunyai self efficacy yang tinggi mau mengerjakan tugas-tugas seperti itu. Jika seorang mahasiswa mempunyai kecemasan yang tinggi dan self efficacy yang tinggi, maka dalam menghadapi tugas akhir tidak menjadi masalah, sekalipun menghadapi tugas yang sulit dan menantang, mahasiswa dapat mengatakan pada dirinya bahwa "aku bisa", setelah itu dapat dengan segera menghadapi tugas akhir.

Kecemasan menurut Nevid, dkk (2002:163) merupakan "suatu keadaan aprehensi atau keadaan khawatir yang mengeluhkan bahwa suatu yang buruk akan terjadi”. Berikut terdapat faktor-faktor yang dapat mempengaruhi kecemasan menurut beberapa tokoh, antara lain (Nevid, dkk., 2002:180): (a) Prediksi berlebihan terhadap rasa takut (b) Keyakinan yang irasional (self defeating) (c) Sensitivitas kecemasan (d) Self efficacy yang Rendah. Self efficacy menurut Bandura adalah suatu yang mengacu pada seberapa mampu atau siapnya seseorang untuk percaya pada kemampuannya dalam menangani jenis tugas tertentu (Bandura, 1997, 2001,2002 dalam Snowman, dkk. 2009: 278). Bandura mengidentifikasikan empat tipe 
perilaku yang dapat berdampak pada level self efficacy individu (Snowman, dkk. 2009: 280), yaitu (a) Selection Processes (b) Cognitive Processes (c) Motivational Processes (d) Affective Prosesses.

Berdasarkan salah satu faktor yang dapat mempengaruhi kecemasan yaitu self efficacy yang rendah. Keterkaitan antara kecemasan menghadapi tugas akhir dengan self efficacy adalah jika mahasiswa percaya bahwa tidak punya kemampuan untuk menanggulangi tantangantantangan yang penuh stress dalam menghadapi tugas akhir, maka mahasiswa tersebut akan merasa semakin cemas bila berhadapan dengan tantangan-tantangan tersebut. Ketika mahasiswa mempunyai self efficacy yang tinggi maka mahasiswa tersebut dapat mengatasi kecemasan yang dihadapinya dan keadaan yang menantang ataupun yang sulit tersebut dapat diibaratkan suatu tantangan yang tidak perlu dihindari.

Dalam penelitian yang dilakukan oleh Barrows, dkk (2013) menunjukkan adanya hasil yang kuat tentang hubungan antara kecemasan dan nilai ujian, serta self efficacy dan nilai ujian. Peneliti menemukan hubungan antara self efficacy dan prestasi akademik mahasiswa, semakin tinggi self efficacy yang dimiliki seorang mahasiswa maka semakin mereka akan merasa dapat melakukannya dengan baik dan ini akan membantu mahasiswa melakukannya dengan baik dalam ujian. Penelitian saat ini menunjukkan hasil adanya efek yang sama dalam satu ujian saja, tidak dari nilai keseluruhan yang berupa IPK. Tingkat kecemasan dalam ujian terjadi sebelum ujian dan dapat meramalkan nilai ujian mahasiswa. Dalam penelitian Barrows, dkk (2013) ini menunjukkan pentingnya untuk menurunkan kecemasan dan meningkatkan self efficacy pada mahasiswa karena dalam hal ini dapat mempengaruhi hasil ujian yang dilakukan mahasiswa.

Penelitian yang dilakukan oleh Rezaei dan Miandashti (2013) menunjukkan adanya hubungan yang negatif antara kecemasan dan self efficacy dalam melakukan penelitian. Studi ini menemukan bahwa ada korelasi positif dan signifikan secara statistik antara self efficacy dalam melakukan penelitian dengan usia mahasiswa, artinya seiring dengan bertambahnya usia, self efficacy meningkat dalam melakukan penelitian. Dengan kata lain, siswa yang lebih tua lebih percaya diri dalam kemampuan mereka melakukan penelitian dibanding mahasiswa yang lebih muda. Temuan lain menunjukkan bahwa adanya hubungan positif dan statistik yang signifikan antara penelitian self efficacy dengan jumlah makalah yang diterbitkan oleh mahasiswa, artinya mahasiswa dengan hasil penelitian yang

Berdasarkan uraian di atas, hipotesis yang diajukan dalam penelitian ini adalah "ada hubungan antara self efficacy dan kecemasan dalam menghadapi tugas akhir pada mahasiswa UKWMS. 


\section{METODE PENELITIAN}

Populasi dalam penelitian ini adalah sebagai berikut:

a. Mahasiswa/mahasiswi Strata satu UKWMS.

b. Mahasiswa/mahasiswi yang menghadapi tugas akhir.

c. Mahasiswa/mahasiswi pada tahap perkembangan minimal remaja akhir (minimal 18 tahun).

Penelitian ini mengunakan proportional stratified random sampling. Proportional stratified random sampling itu sendiri adalah "teknik penentuan sample dengan cara membuat lapisanlapisan kemudian dari setiap lapisan diambil sejumlah subjek secara acak" (Sugiyono, 2006:92). Pada pengambilan sample ini semua fakultas mewakili sebagai sample dan dikelompokkan menurut tingkat fakultas. Peneliti mengambil jumlah anggota sample dari populasi tertentu dengan menggunakan Nomogram Herry King (Sugiyono, 2006:96). Dengan menggunakan Nomogram Herry King, berdasarkan data dari tata usaha setiap fakultas, jumlah populasi pada penelitian ini 727 subjek, peneliti menggunakan taraf kesalahan 1\% maka jumlah sampelnya 341. Untuk menentukan sampel perstrata, adanya rumus sebagai berikut:

Sampel perstrata $=$ jumlah subjek dalam suatu strata $\mathrm{x}$ jumlah sampel jumlah keseluruhan populasi

Skala yang peneliti gunakan adalah skala likert sehingga dalam penelitian ini menggunakan skala self efficacy dan skala kecemasan. Pengolahan data dalam penelitian ini menggunakan Statistika Parametrik Kendall's Tau b atau statistika non parametric. Uji asumsi yang harus dilakukan adalah uji normalitas dan uji linieritas. Berdasarkan pada pengolahan data menggunakan uji normalitas maka diperoleh signifikansi variabel kecemasan dalam menghadapi tugas akhir sebesar 0,001. Dari perolehan data tersebut dapat disimpulkan bahwa variabel kecemasan dalam menghadapi tugas akhir tidak normal karena nilai sig kurang dari 0,05. Berdasarkan pada pengolahan data menggunakan uji normalitas maka diperoleh signifikansi variabel self efficacy sebesar 0,000. Dari perolehan data tersebut dapat disimpulkan bahwa variabel self efficacy tidak normal karena nilai sig kurang dari 0,05.

Hasil uji linieritas menunjukkan nilai sig 0,000. Dengan demikian hubungan antara kecemasan menghadapi tugas akhir dengan self efficacy dapat dikatakan linier karena nilai sig kurang dari 0,05 . Uji hipotesis dalam penelitian ini menggunakan kendall's tau $b$ karena uji normalitas tidak terpenuhi. Dikarenakan uji asumsi normalitas kedua variabel tidak memenuhi dan uji linieritas tidak memenuhi syarat maka pengolahan data menggunakan statistika non parametrik Kendall's Tau b. Dari proses pengolahan data, didapatkan hasil nilai koefisiensi korelasi antara kecemasan menghadapi tugas akhir dan self efficacy sebesar -0,376 dengan nilai 
signifikansi 0,000. Berdasarkan pada arah hubungan dalam penelitian ini, arah hubungannya negatif maka semakin tinggi kecemasan maka semakin rendah self efficacy, begitu pula sebaliknya.

\section{DISKUSI}

\section{Hasil Penelitian}

Pada penelitian ini menunjukkan ada hubungan karena sesuai dengan pembahasan teori yang dilakukan pada bab sebelumnya yaitu salah satu faktor kecemasan adalah self efficacy yang rendah (Nevid, dkk, 2000:180). Hasil penelitian ini juga didukung oleh penelitian Wardhani (2015) tentang hubungan antara self efficacy dengan kecemasan menghadapi ujian skripsi pada mahasiswa psikologi Universitas Muhammadyah Surakarta. Wardhani mendapatkan hasil bahwa ada hubungan yang signifikan antara self efficacy dengan kecemasan menghadapi ujian skripsi. Demikian pula hasil penelitian yang dilakukan oleh Jannah (2015) tentang hubungan antara efikasi diri dengan kecemasan menghadapi ujian SBMPTN yang menyatakan bahwa terdapat hubungan negatif antara efikasi diri dengan kecemasan menghadapi ujian SBMPTN. Berdasarkan penelitian yang dilakukan oleh peneliti serta penelitian yang dilakukan Wardhani dan Jannah, dapat disimpulkan adanya hubungan antara self efficacy dan kecemasan.

Berdasarkan pada data menunjukkan bahwa kecemasan mahasiswa UKWMS paling banyak pada kategori sedang. Hal tersebut dikarenakan mahasiswa UKWMS dalam menghadapi tugas akhir banyak melalui proses yang meliputi pengambilan data, pengolahan data, pembahasan hasil sampai dengan sidang dan setiap individu memiliki perbedaan antar stressor yang dihadapi dan belum tentu individu tersebut dalam menghadapi tugas akhir sedang mendekati stressor tersebut. Stressor yang paling banyak dialami adalah tentang pengerjaan tugas akhir yang melebihi deadline, saat sidang, pengambilan data dan saat pembuatan laporan. Dalam penelitian Jannah (2015), kecemasan siswa yang sedang menghadapi ujian SBMPTN masuk dalam jenis kecemasan state anxiety. State anxiety adalah bahwa semakin mendekati waktu ujian SBMPTN, maka kecemasan siswa akan meningkat. Jadi dapat disimpulkan bahwa ketika mahasiwa sedang mengisi kuesioner, belum tentu mahasiswa tersebut sedang berada pada stressor yang dicemaskan dan berdasarkan hal tersebut membuat data dalam kategori kecemasan paling banyak terdapat pada kategori sedang.

Berdasarkan perhitungan SPSS diperoleh correlation coefficient -0,376, dan nilai tersebut memiliki kekuatan korelasi pada kategori sedang (Pallant, 2013:121). Jadi kekuatan korelasi 
self efficacy terhadap kecemasan tergolong mempunyai hubungan yang cukup kuat dengan persentase sebesar $14 \%$, sementara kemungkinan sebesar $86 \%$ bisa dipengaruhi oleh variabel lain yang tidak diteliti, seperti regulasi diri. Regulasi diri ini didapatkan berdasarkan hasil wawancara pada 8 Februari 2017 dengan beberapa mahasiswa UKWMS di preliminary data. Mahasiswa UKWMS mempunyai pertimbangan dalam melakukan tujuan yang dilakukan dalam menghadapi tugas akhir, seperti membuat jadwal pengerjaan tugas akhir ataupun target yang perlu dicapai dalam menghadapi tugas akhir. Berdasarkan preliminary yang dilakukan oleh peneliti pada tanggal 1 Maret 2017, sebanyak 19 mahasiswa melakukan aktivitas lain selain mengerjakan tugas akhir, seperti jalan-jalan, bermain HP, mengerjakan tugas matakuliah lain dan beristirahat terlebih dahulu untuk menenangkan pikiran sebelum mengerjakan tugas akhir. Pada fenomena tersebut, terdapat mahasiswa UKWMS yang sepertinya melakukan prokastinasi. Variabel lain yang tidak tampak pada fenomena bisa berupa dukungan sosial (Yunita, 2013), religiusitas (Hidayatin \& Darmawati, 2013) dan sebagainya.

Selain dari faktor usia yang dapat membuat kecemasan mahasiswa Fakultas Filsafat UKWMS pada kategori rendah, juga adanya faktor regulasi diri. Berdasarkan wawancara dengan salah satu mahasiswa Fakultas Filsafat pada tanggal 27 November 2017, sistem pengerjaan tugas akhir di Fakultas Filsafat adalah mahasiswa dapat mengerjakan proposal skripsi pada semester enam dan skripsi pada semester tujuh dan delapan; akan tetapi dalam KRS akan dicantumkan matakuliah skripsi pada semester delapan saja. Dari adanya jangka waktu yang panjang dalam mengerjakan tugas akhir, mahasiswa ini menentukan target yang hendak dicapai dalam mengerjakan tugas akhirnya karena mengingat kegiatan pada mahasiswa Fakultas Filsafat tidak hanya di kampus saja akan tetapi juga adanya kegiatan atau tugas di seminari. Jadi dapat disimpulkan bahwa mahasiswa Fakultas Filsafat UKWMS dalam menghadapi tugas akhir memiliki level kecemasan pada kategori rendah karena memiliki usia lebih tua dari rata-rata usia mahasiswa lainnya. Seiring dengan bertambahnya usia, self efficacy juga meningkat dan adanya regulasi diri. Dengan adanya kemampuan mahasiswa Fakultas Filsafat dalam menggunakan potensinya untuk memonitor, mengatur dan mengontrol kognisi, motivasi, dan perilakunya dalam menghadapi tugas akhir, maka mahasiswa tersebut dapat mengontrol dorongan pikiran dan perasaan akan ketakutan dalam menghadapi tugas akhir.

Berdasarkan hasil wawancara dengan salah satu mahasiswa Fakultas Teknik UKWMS pada tanggal 17 November 2017, adanya banyak proses yang perlu dilalui oleh mahasiswa Fakultas Teknik dan jika mahasiswa Fakultas Teknik belum menyelesaikan satu proses maka mahasiswa 
tersebut tidak dapat melanjutkan pada proses selanjutnya. Berdasarkan fenomena terebut, yaitu adanya mahasiswa yang belum disetujui judul skripsinya dan kejadian tersebut dapat memunculkan pengalaman negatif, bisa jadi dari fenomena tersebut membuat mahasiswa merasa cemas. Berdasarkan penelitian yang dilakukan oleh Riani dan Rozali (2014) tentang hubungan antara self efficacy dan kecemasan saat presentasi pada mahasiswa Universitas Esa Unggul, didapatkan koefisien korelasi sebesar -0,589 dengan sig 0,000 ( $\mathrm{p}<0,05)$, artinya ada hubungan negatif signifikan antara self efficacy dengan kecemasan saat presentasi pada mahasiswa Universitas Esa Unggul. Riani dan Rozali juga menyatakan bahwa adanya faktor pengalaman negatif pada masa lalu yang mengakibatkan kecemasan. Jadi dapat disimpulkan bahwa mahasiswa Fakultas Teknik UKWMS memiliki level kecemasan pada kategori tinggi dan sangat tinggi paling banyak kemungkinan dikarenakan adanya faktor pengalaman negatif dari setiap proses yang mereka lewati dalam menghadapi tugas akhir, contohnya seperti judul tugas akhir yang ditolak.

Pengerjaan tugas akhir di Fakultas Filsafat yang memulai dapat proposal skripsi pada semester enam dan skripsi pada semester tujuh dan delapan, sedangkan di Fakultas Teknik dalam penentuan judul, pengolahan data, sidang seminar, pembuatan laporan, dan sidang skripsi ditempuh selama satu semester serta adanya kerja praktek pada semester berikutnya. Sistem pengerjaan tugas akhir yang seperti itu kemungkinan dapat menentukan tinggi rendahnya kecemasan pada mahasiswa dalam menghadapi tugas akhir. Hal tersebut dapat dilihat dari salah satu hasil penelitian Pratiwi (2009), ditemukan adanya usaha pihak sekolah untuk menurunkan level kecemasan siswa supaya tidak perlu lagi khawatir tentang program Sekolah Berstandar Internasional (SBI) yang masih dalam rintisan ini dengan cara mengimbangi kurikulum internasional yang menjadi bagian dari Kegiatan Belajar Mengajar (KBM) dengan pelayanan yang lebih canggih sehingga mempermudah siswa dalam proses belajar di sekolah. Mengingat penelitian ini menggunakan mahasiswa yang sedang mengerjakan tugas akhir sehingga peneliti sedikit mengalami kesulitan untuk mencari mahasiswa-mahasiswa tersebut. Hal tersebut dikarenakan tidak semua mahasiswa pergi ke kampus setiap hari sehingga penelitian membutuhkan waktu yang lama dalam penyelesaiannya. Hal tersebut itu pulalah yang menyebabkan peneliti menggunakan google form dalam penyebaran alat ukur yang menyebabkan peneliti tidak dapat mendampingi subjek dalam penyelesaian pengerjaan kuesionernya.

\section{Kesimpulan \& Saran}


Berdasarkan hasil analisis data dan pembahasan pada penelitian ini, didapatkan nilai koefisiensi korelasi antara kecemasan menghadapi tugas akhir dan self efficacy sebesar -0,376 dengan nilai signifikansi 0,000 , maka dapat dikatakan adanya hubungan negatif antara kecemasan menghadapi tugas akhir dengan self efficacy. Pada nilai koefisiensi korelasi dengan arah negatif, dapat disimpulkan semakin tinggi kecemasan maka semakin rendah self efficacy, begitu pula sebaliknya. Koefisien determinasi yang sebesar 14\% memiliki arti self efficacy memberi sumbangan sebesar $14 \%$ terhadap kecemasan dan $86 \%$ dikarenakan variabel lain yang tidak diteliti dan terjadi difenomena seperti regulasi diri dan prokastinasi atau variabel lain yang tidak tampak pada fenomena bisa berupa hal lain seperti dukungan sosial (Yunita, 2013), religiusitas (Hidayatin \& Darmawati, 2013) dan sebagainya. Bagi semua fakultas, mengacu pada hasil penelitian yang diperoleh, masih ada mahasiswa yang memiliki kecemasan sangat tinggi dan tinggi dengan self efficacy sedang dan rendah. Disarankan bagi fakultas untuk dapat memotivasi mahasiswa supaya dapat menurunkan kecemasan dan meningkatkan self efficacy dalam menghadapi tugas akhir dengan menagdakan kegiatan-kegiatan/pelatihan sejenis yang dapat membantu mahasiswa merasa tenang dalam menghadapi tugas akhir apapun bentuknya. Bagi penelitian selanjutnya dapat mengkaitkan kecemasan dalam menghadapi tugas akhir dengan regulasi diri, dukungan sosial atau prokastinasi atau variabel lainnya.

\section{Referensi}

American Psychiatric Association. (2013). Diagnostic and statistical manual of mental disorder $5^{\text {th }}$ edition. Washinton DC: American Psychiatric Publishing. Washinton DC.

Anggen, C. N. (2012). Pengaruh relaksasi visualisasi imagery untuk menurunkan kecemasan dalam menghadapi ujian skripsi. (Skripsi tidak diterbitkan). Surabaya: Universitas Katolik Widya Mandala Surabaya.

Azwar. (2007). Tes prestasi. Yogyakarta: PUSTAKA PELAJAR.

Barrows, J., Samantha, D., \& Carrie, A. L. (2013). Anxiety, self-efficacy, and college exam grades. Universal Journal of Educational Research, 1(3). 204-208. Diunduh pada tanggal 3 Maret 2017 dari http://www.hrpub.org/journals/article info.php?aid=559.

Fatima, I., \& Wafa, K. (2013). Emotional intelligence, anxiety and procrastination in intermediate science students. Pakistan journal of social and clinical psychology, 11(2). 3-6. Diunduh pada tanggal 3 Maret 2017 dari http://www.gcu.edu.pk/FullTextJour/PJSCS/2013b/1.iramFatima.pdf.

Hidayatin, A., \& Darmawanti, I.(2013). Hubungan antara religiusitas dan self efficacy dengan kecemasan menghadapi ujian nasional pada mahasiswa kelas XII man 1 model bojonegoro. Character, 2(1). 6. Diunduh pada tanggal 4 Januari 2017 dari http://jurnalmahasiswa.unesa.ac.id/index.php/character/article/view/4581. 
HIMPSI. (2010). Kode etik psikologi indonesia. Jakarta: Pengurus Pusat Himpunan Psikologi Indonesia.

Husnia. (2015). Hubungan prokastinasi akademik tehadap tingkat kecemasan pada mahasiswa psikologi angkatan 2011 uin maliki malang. (Skripsi tidak diterbitkan). Malang: UIN Maulana Malik Ibarahim. Diunduh pada tanggal 3 Maret 2017 dari http://etheses.uinmalang.ac.id/3148/1/11410134.pdf.

Jannah, A. M. (2015). Hubungan antara efikasi diri dengan kecemasan menghadapi ujian sbmptn. (Skripsi tidak diterbitkan). Surakarta: Universitas Muhammadyah Surakarta. $\begin{array}{llllll}\text { Diunduh pada tanggal } & 10 & \text { Januari } & 2017 & \text { dari }\end{array}$ http://eprints.ums.ac.id/35103/4/02.\%20Naskah\%20Publikasi.pdf.

Maltby., Gage. \& Berliner. (1995). Educational psychology: An Australian and New Zealand perspective. Sydney: JOHN WILEY \& SONS.

Nevid, J. S., Rathus, S. A. \& Greene, B. (2003). Psikologi abnormal. Jakarta: Penerbit Erlangga.

Ormrod, J. E. (2008). Psikologi pendidikan membantu siswa tumbuh dan berkembang. Pearson : PT Gelora Aksara Pratama.

Pallant, J. (2013). SPSS Survival Manual A Step by Step Guide to Data Analysis Using SPSS for Windows fifth edition. New York: McGraw-Hill Education-Open University Press.

Pratiwi, A. P. (2009). Hubungan antara kecemasan akademis dengan self-regulated learning pada siswa rintisan sekolah bertaraf internasional di SMA negeri 3 Surakarta. (Skripsi tidak diterbitkan). Semarang: Universitas Diponegoro. Diunduh pada tanggal 27 November 2017

dari https://www.google.com/search?q=Pratiwi $\% 2 \mathrm{C}+\mathrm{A} .+\% 282009 \% 29 .+$ Hubungan + antara + kecemasan+akademis + dengan + se; fregulatd + learning + pada + siswa + rintisan + sekolah + bertaraf + internasional + di $+\mathrm{SMA}+\mathrm{Neg}$ eri $+3+$ Surakarta. + Fakultas + Psikologi + Universitas + Diponegoro + semarang. $\&$ client $=\mathrm{ms}-$ opera-mobile\&channel=new

Riani, W. S., Rozali, Y. A. (2014). Hubungan antara self efficacy dan kecemasan saat presentasi pada mahasiswa univeristas esa unggul. Jurnal psikologi, 12(1),1-9. Diunduh pada tanggal $10 \quad$ Januari 2017 dari http://download.portalgaruda.org/article.php?article=327294\&val=4564\&title=Hubung an $\% 20$ Antara $\% 20$ Self $\% 20$ Efficacy $\% 20 \% 20$ dan $\% 20$ Kecemasan $\% 20$ Saat $\% 20$ Presentasi \%20pada\%20Mahasiswa\%20Univeristas\%20Esa\%20Unggul.

Rezaei, M., \& Miandashti, N. Z. (2013). The relationship between research self-efficacy, research anxiety and attitude toward research: a study of agricultural graduate students. JOURNAL OF EDUCATIONAL AND INSTRUCTIONAL STUDIES IN THE WORLD, 3(9). 69-78. Diunduh pada tanggal 3 Maret 2017 dari http://www.wjeis.org/FileUpload/ds217232/File/09c.rezaei.pdf.

Sanitiara., Firdaus. \& Nazriati, E. (2014). Hubungan kecemasan akademis dengan regulasi diri dalam belajar pada mahasiswa tahun pertama fakultas kedokteran universitas riau tahun 
2013/2014. JOM FK, 1(2),1-9. Diunduh pada tanggal 14 Februari 2017 dari http://download.portalgaruda.org/article.php?article $=186976 \& v a l=6449 \&$ title $=$ HUBU NGAN\%20KECEMASAN\%20AKADEMIS\%20DENGAN\%20REGULASI\%20DIRI \%20DALAM \%20BELAJAR\%20PADA\%20MAHASISWA\%20TAHUN\%20PERTA MA\%20FAKULTAS\%20KEDOKTERAN\%20UNIVERSITAS\%20RIAU\%20TAHU N\%202013/2014.

Santoso, S. (2010).Statistik multivariat.Jakarta: PT Elex Media Komputindo.

Santrock, J. W. (2007).Remaja, Edisi kesebelas.Surabaya: Penerbit Erlangga.

Santrock, J. W. (2011). Psikologi pendidikan edisi 2. Jakarta: Kencana.

Snowman, J., McCrown, R. \& Biehler, R. (2009). Psychology applied to teaching (12 ${ }^{\text {th }}$ Ed). Boston: Houghton Mifflin Co.

Sugiyono. (2006). Metode penelitian kuantitatif, kualitatif dan r \& d. Bandung: Penerbit Alfabeta.

UKWMS. (2014). Peraturan akademik 2014. Surabaya: UKWMS.

Wardhani, D. K, (2015). Hubungan antara self efficacy dengan kecemasan menghadapi ujian skripsi pada mahasiswa psikologi universitas muhammadyah surakarta. (Skripsi tidak diterbitkan). Surakarta: Universitas Muhammadyah Surakarta. Diunduh pada tanggal 10 Januari 2017 dari http://eprints.ums.ac.id/38873/2/03.\%20HALAMAN\%20DEPAN.pdf.

Yunita, K. H. (2013). Hubungan dukungan sosial orang tua dengan kecemasan dalam menghadapi ujian nasional pada siswa kelas IX smp "x" di semarang. (Skripsi tidak diterbitkan). Semarang: Universitas Katolik Soegijapranata. Diunduh pada tanggal 10 Januari 2017

https://www.google.co.id/url? sa =t\&rct=j\&q=\&esrc=s\&source=web\&cd=1\&cad=rja\&u act $=8 \& v e d=0$ ahUKEwjews $\mathrm{j}$ pfXAhXEQY8KHVB-

CF0QFggnMAA\&url=http\%3A\%2F\%2Fid.portalgaruda.org\%2Findex.php $\% 3$ Fpage $\%$ 3D1\%26ipp\%3D100\%26ref\%3Dbrowse \%26mod\%3Dviewjournal\%26journal\%3D553 6\&usg=AOvVaw1TepP9oWTw0iwDF-CKcMiK. 